\title{
SUPPLY CHAIN MANAGEMENT, SUPPLY CHAIN FLEXIBILITY AND BUSINESS PERFORMANCE
}

\begin{abstract}
Arawati AGUS
ABSTRACT

Universiti Kebangsaan Malaysia,

Supply chain performance and effective management of supply chain have been increasingly recognized as critical factors in enhancing bottom-line performances. More and more firms are beginning to adopt supply chain management (SCM) to improve performances of their organizations. This study examines the importance of incorporating supply chain management in Malaysian manufacturing companies. The study measures senior production or SCM managers' perceptions regarding SCM practices and performances of their companies. The paper specifically investigates relationship between SCM, supply chain flexibility and business performance and these associations are analyzed through statistical methods such as Pearson's correlation and structural equation modeling (SEM). The overall result suggests that supply chain management has significant correlations with supply chain flexibility and business performance. Specifically, supply chain flexibility and business performance have high correlations with SCM comprising programs such as 'strategic supplier partnership', 'lean production', 'postponement concept' and 'technology and innovation'. In addition, the SEM result also demonstrates that two supply chain management proxies specifically 'new technology and innovation' and 'lean production' appear to be of primary importance and exhibit most significant impact on supply chain flexibility and business performance. Findings of the study provide striking demonstrations of the importance of SCM programs in enhancing performances of Malaysian manufacturing companies. The result indicates that manufacturing companies should emphasize greater attention to the technology aspects of SCM as well as waste reduction program through lean production and a greater degree of management support for SCM enhancement initiatives.
\end{abstract}

Keywords: Supply Chain Management, Supply Chain Flexibility, Business Performance, Structural Equation Modeling, Program Theory

\section{INTRODUCTION}

Today's global marketplace offers tremendous opportunities for manufacturing companies in achieving strategic competitiveness through effective supply chain management (SCM). The current environment, in which organizations operate, has changed drastically with the growth in collaboration between competitors, supply chain partners, outsourcing, integrated supply chain systems and advancement in technology and innovation. As global competition increases, manufacturing companies should be more involved in how their suppliers and customers conduct business. They need to focus on SCM programs that have significant impact on enhancing SCM activities such as where quality raw materials come from, how products are designed and assembled, how finished products are distributed and what consumers really need. The process of making and distributing products and services to customers is becoming the most effective and efficient way for companies to stay successful and is central to the practice of supply chain management. Despite several evidences suggesting that performance improvements are related to SCM (Christopher, 1998; Bhasin, 2008), with a few exceptions, rarely support their suggestions with statistical evidences. There are relatively few empirical studies exist to measure the extent of performance improvements resulted from SCM programs especially in the Malaysian context. This paper seeks to address this apparent gap in literature by examining the performance implications of implementing SCM in the manufacturing industry by analyzing data using statistical analyses such as Pearson's correlation and structural equation modeling (SEM).

Simultaneously, this study also tries to explore the possibility of adopting SCM as the basis for enhancing supply chain flexibility and business performance in Malaysian manufacturing companies. Empirically, the purpose of this study is to present an explicit result on the relationship between these research constructs where other researchers have perhaps known or describe them only implicitly. This study is one of few attempts to estimate the effect of implementing SCM programs on supply chain flexibility and business performance. It fills a gap that exists in the literature on SCM studies. The main objectives of this study are: 
a-To empirically assess the importance of each SCM dimension on performance.

b-To empirically determine whether SCM has significant impact on supply chain flexibility.

c-To empirically discover whether SCM has significant impact on business performance.

d-To empirically investigate whether supply chain flexibility has significant impact on business performance.

e-To empirically test whether supply chain flexibility mediates the linkage between SCM and business performance.

First, this study proceeds with a brief explanation on the supply chain management principles and literature review; second, it highlights the conceptual framework which includes the explanation of the conceptual model, the underpinning theory, and hypotheses. Third, it discusses the methodology adopted, and statistical tests conducted to obtain reliable and valid measures of constructs and variables. Fourth, it highlights the preliminary statistical analyses which include correlations between SCM, supply chain flexibility and business performance. Fifth, it presents the result of structural equation modeling (SEM). Finally, the overall findings are then discussed and implications highlighted.

\section{SUPPLY CHAIN MANAGEMENT (LITERATURE REVIEW)}

Supply chain management (SCM) is a set of managerial practices which includes sourcing raw materials, manufacturing and assembling products, managing warehousing and inventory, monitoring supply and demand, distributing and delivering finished products to the customer (Windischer \& Grote, 2003; Agus, 2010). Various definitions have been used to explain the term SCM. Schonsleben (2004) defines SCM as coordination of strategic and long-term cooperation in logistics networks (Windischer \& Grote, 2003). According to Quinn (1997), the supply chain includes all of those activities associated with moving goods from the raw-materials stage through to the end user. This includes sourcing and procurement, production scheduling, order processing, inventory management, transportation, warehousing and customer service. SCM also embodies the information systems which are necessary to monitor all of those activities. SCM coordinates and integrates all of the supply chain activities and also links all of the partners in the chain, including departments within an organization and external companies and information systems providers (Lummus \& Vokurka, 1999; Agus \& Hassan, 2008). A key point in SCM is that the entire process must be viewed as one system. This definition highlights the importance of managing boundaries between supply chain partners. Ganeshan and Harrison (1999) define supply chain as a network of facilities and distribution options that performs the functions of procurement of materials, transformation of these materials into intermediate and finished products, and the distribution of these finished products to customers. To improve performance, organizations have to adopt SCM approach and consider the supply chain as a whole. Several researchers claimed that SCM can result in better supply chain performance and bottom line results (Christopher, 1998; Bhasin, 2008; Agus, 2010).

\section{THE CONCEPTUAL FRAMEWORK - THE CONCEPTUAL MODEL, THE UNDERPINNING THEORY AND HYPOTHESES}

\section{The Conceptual Model}

The proposed model (Figure 1) is based on three main constructs- (i) Supply chain management (SCM); (ii) Supply chain flexibility (SCFLEX) and (iii) Business performance (BUSPERF). In this study, in order to determine the domain that encompasses SCM dimensions, exhaustive theoretical, empirical and practitioner literature were reviewed (Li, Ragu-Nathan, Ragu-Nathan, \& Rao, 2006; Womack \& Jones, 2003; Van Hoek, 2001; Agus, 2010b). Incorporating ideas, theories and studies from literature, four main SCM dimensions included in the study are:

a- Strategic Supplier Partnership (MN1SSP): Developing trust and collaboration among supply chain partners as well as customers (Li, Ragu-Nathan, Ragu-Nathan, \& Rao, 2006; Agus \& Hassan, 2008).

b- Lean Production (MNB5LS): Lean production is associated with continuous pursuit of improving the processes, a philosophy of eliminating all non-value adding activities and reducing waste within an organization (Womack \& Jones, 2003; Agus, 2010a). 
c- Postponement Concept (MNB6PC): Postponement involves the process of delaying final product configuration until the actual order requirement is specified by the customer. Keeping products in semi-finished would allow more flexibility and customization in completing the final products and also enables a company to respond more quickly to market demand (Van Hoek, 2001, Agus, 2009).

d- New Technology and Innovation (MB7TECH): Tremendous change in the technological developments and globalization has formed significant impact on the nature of work where advanced use of technology is a necessity in order to compete in the global arena (Singh \& Singh 2008). New technology and innovation in SCM refers to the application of the latest scientific or engineering discoveries to the design of operations and production processes (Agus, 2008, 2010b).

This study investigates the influence of SCM on two performance measures namely supply chain flexibility and business performance. Supply chain flexibility is vital to the success of the supply chain since the supply chain exists in an uncertain environment. It can measure the degree to which the supply chain can respond to random fluctuations in the demand and supply changes. Flexibility may be defined as the ability to change or react with little penalty in time, effort, cost or performance (Upton, 1994). Flexibility can improve the company's competitiveness, particularly for the decisionmaking process of implementing technologies (Jaikumar, 1986; Alvarez-Gil, 1994). To this regard, some scholars (Brill \& Mandelbaum, 1989; Gerwin, 1993) think that a flexible operations system requires the management and control of different flexibility dimensions, by analysing the total system flexibility. Flexibility is viewed as a reaction to environmental uncertainty (Riley \& Lockwood, 1997) and can be an important source of competitive advantage, since material flows strongly affect business performance. In this study, in order to capture the multi-dimensional nature of performance measures and incorporating ideas, theories and studies from literature, supply chain flexibility is operationalised by 'Product Flexibility', 'Volume Flexibility' and 'Launch / New Product Flexibility' (Vickery et al. 1997 , Cleveland, Schroeder \& Anderson, 1989; Lieberman \& Montgomery, 1988; Robinson, Fornell \& Sullivan, 1992):

Product flexibility (PRODFLEX) - the ability to customize product or service to meet customer specification. Vickery et al. (1997) define product flexibility in a supply chain framework as the ability to handle difficult, non-standard orders, to meet special customer specifications, and to produce products characterised by numerous features, options, sizes, and colours.

Volume flexibility (VOLFLEX) - the ability to adjust capacity to meet changes in customer demand quantities. Volume flexibility is defined as the ability to effectively increase or decrease aggregate production in response to customer demand (Cleveland, Schroeder \& Anderson, 1989). Volume flexibility may require close coordination between a manufacturer and its suppliers, especially in the face of increasing demand.

c) Launch/New product flexibility (NEWPFLEX) - the ability to launch new or revised product. The ability to rapidly introduce many new products and product varieties is a strategically important flexibility that requires the integration of numerous value activities across the entire supply chain. As product life cycles decrease, increasing strategic emphasis is being placed on bringing many new products to market as quickly as possible (Lieberman \& Montgomery, 1988; Robinson, Fornell \& Sullivan, 1992).

On the other hand, business performance is a very important bottom-line outcome and in this study that construct is operationalised by indicators namely 'Return on Sales', 'Return on Assets' and 'Financial Performance' (Investorwords, 2010).

Return on Sales (ROS): A measure of a company's profitability, equal to a fiscal year's pre-tax income divided by total sales. [Our Company's 'return on sales' is high relative to our competitors].

Return on Assets (ROA): A measure of a company's profitability, equal to a fiscal year's earnings divided by its total assets, expressed as a percentage. [Our Company's 'return on assets' is high relative to our competitors].

Financial Performance (FINPERF): The account status of a firm's or individual's assets, liabilities, and equity positions as reflected on its financial statement. [Our Company's financial performance is high relative to our competitors]. 


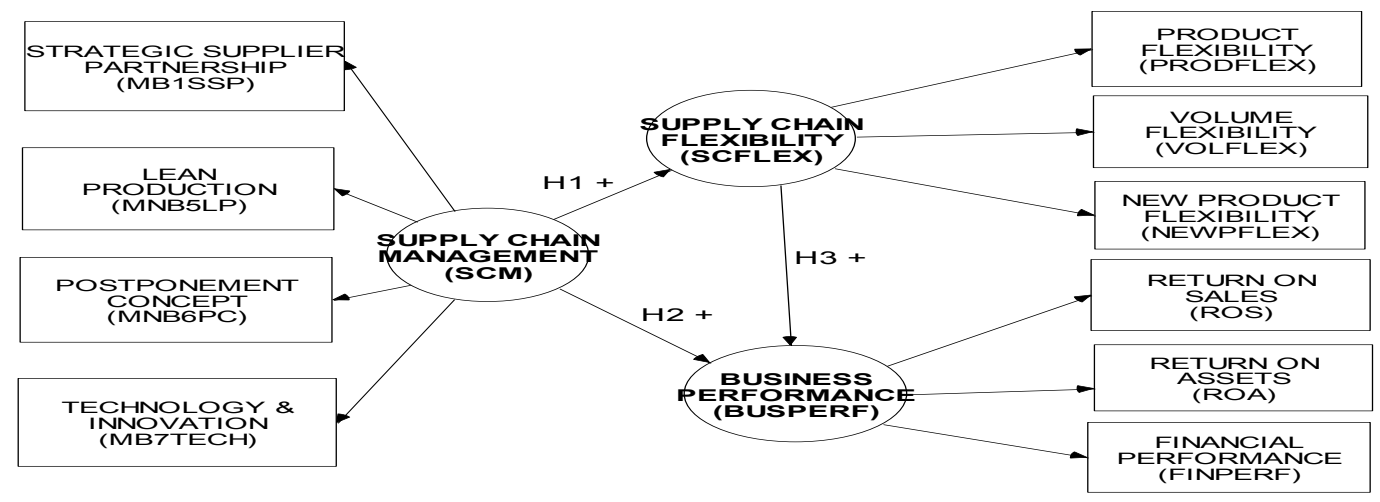

Figure 1: The Conceptual Framework Linking Supply Chain Management, Supply Chain Flexibility and Business Performance

\section{The Underpinning Theory}

The underpinning theory that governs the theoretical framework of this paper is program theory. Program theory (Weiss, 1998) focuses on the model underlying a technical program. Program theory links inputs with activities to outcomes. For instance, SCM is geared to identify new production methods and innovation in order to push the company ahead which provides a rationale for the program. In other words, program theory describes what the intended intervention is expected to do and an explanation of the underlying rationale for achieving the expected results. Weiss (1998) defines program theory as 'theories of change' relating programs to desired outcomes. All programs have an underlying logic or a set of explicit and often, implicit assumptions that suggest how the desired outcomes should be affected by variables in their context, as well as by program inputs and processes. The program theory is most obvious if there are clearly stated program goals, such as performances (Bickman, 2000; Suchman, 1967). The programs investigated in this study are 'SCM' programs/ dimensions. The outcome here refers to 'supply chain flexibility' and 'business performance'. The SCM programs create value by focusing on key performance gap which in turn helps a company to identify new ideas and innovation in order to push the company ahead. 'SCM' programs improve processes and help to enhance 'supply chain flexibility'. As a result, it will ultimately improve the 'business performance' against its competitors (Bickman, 2000; Suchman, 1967).

\section{Hypotheses}

The study proposes that supply chain management (SCM) has important influence on supply chain flexibility and business performance results. A structural equation model is used in this study to analyze the structural effect of SCM dimensions on these performance results. In this study, firstly, the study aims to test the fitness of the overall SEM model based on the main null hypothesis:

\section{$H_{0}$ : The overall hypothesized model has a good fit.}

For structural modeling, accepting this null hypothesis indicates that the model presented adequately reproduce the observed covariance matrix (Bollen, 1989; Joreskog, 1989; Mueller, 1996) and suggests that the data fit the proposed SEM model. Therefore, in the test of goodness of fit for the structural equation modeling, the probability that is expected should not be significant (probability value $>0.05$ ) to support the overall null hypothesis which suggests that the overall hypothesized model has a good fit.

Then secondly, the study attempts to investigate the main research hypotheses regarding associations between SCM, supply chain flexibility and business performance. The first research hypothesis states that implementing effective SCM enhances supply chain flexibility. The second hypothesis proposes that implementing SCM improves business performance. The third hypothesis proposes that supply chain flexibility has a positive effect on business performance. In addition, this study also tries to test (fourth hypothesis) whether there is a mediating effect of supply chain flexibility in the linkage between SCM and business performance. Therefore, the following main research hypotheses are investigated: 
$H_{1}$ : Supply chain management has a positive structural effect on supply chain flexibility.

$\mathrm{H}_{2}$ : Supply chain management has a positive structural effect on business performance.

$H_{3}$ : Supply chain flexibility has a positive structural effect on business performance.

$\mathrm{H}_{4}$ : Supply chain flexibility mediates the linkage between SCM and business performance.

\section{RESEARCH METHODOLOGY}

The study was a quantitative, cross-sectional research utilizing primary data collection. The unit of analysis chosen for this study was company level and each company was being represented by a production, SCM or senior manager (as the respondents). The sampling frame was derived from the Federation of Malaysian Manufacturing Companies Directory (FMM). Two hundred and fifty useable responses were analyzed using the SPSS package. Face to face interviews with these managers were conducted by enumerators for checking the information accuracy, validating the outcome of analysis and developing an understanding of practical aspects of SCM.

The research instrument used in this study was a structured survey questionnaire, which was designed to assess the companies in term of the described dimensions. The instrument designed consisted of two major parts. The first part comprised several constructs measuring SCM practices, and the second part captured several performance measurements. To enable respondents to indicate their answers, seven-point interval scales were used for the questionnaire on SCM practices. The performance measures namely supply chain flexibility and business performance also used a seven-point interval scale, representing a range of agreement on statements whether over the past three years these performances were high relative to competitors after implementing SCM. Before creating the final scales, the data were checked for normality and outliers; and were found to be satisfactory.

\section{INDEPENDENT AND DEPENDENT CONSTRUCTS' MEASUREMENT: FACTOR ANALYSIS AND RELIABILITY TEST}

As the initial data analysis, SCM, supply chain flexibility and business performance dimensions or proxies were subjected to factor analysis and reliability test. These tests were computed to select and assess the final items of the constructs that would be utilized for statistical and hypotheses testing. Exploratory factor analysis (EFA) was conducted to investigate whether the factors derived from the exploratory factor analysis fitted the constructs as described theoretically in the literature (Table 1). Results from the EPA indicated that all items had significant loadings on their respective factors with eigen values exceeded 2, and the values of cumulative variance explained ranged from 27.53 to 79.12 (Table 2). In addition, the KMO (Kaiser-Meyer-Olkin) measure was 0.89 with significant chi-square value (Barlett's Test of Sphericity $=1778.26$ ). The value of KMO in this analysis surpassed the threshold value of 0.50 as recommended by Hair, Anderson, Tatham, \& Black (1998). All constructs exhibited high factor loadings and fell into the designated factors. The result provided evidence to support the theoretical conceptualization of the three constructs. Observing the descriptive statistics in Table 1, the result demonstrated that among SCM dimensions, postponement concept had the highest mean (5.31), followed by lean production (5.21), strategic supplier partnership (5.18) and lastly new technology and innovation (4.94). The result suggested that the adoption of new technology and innovation should be enhanced to keep abreast with global manufacturing practices. On the other hand, for supply chain flexibility variables; volume flexibility demonstrated the highest mean (5.21) followed by product flexibility (5.13) and new product flexibility (4.94). Finally, among business performance measures; 'financial performance' (5.22) exhibited the highest mean followed by 'return on sales' (4.96) and 'return on assets' (4.94). 
Table 1: Descriptive Statistics and Factor Analysis

\begin{tabular}{|c|c|c|c|c|c|}
\hline \multirow[t]{2}{*}{ Supply chain management (SCM): } & \multirow[t]{2}{*}{ Mean } & \multirow[t]{2}{*}{$\begin{array}{l}\mathrm{S} \mathrm{t} \mathrm{d} \\
\text { Dev. }\end{array}$} & \multicolumn{3}{|c|}{$\begin{array}{l}\text { Exploratory Factor Analysis } \\
\text { (Varimax Rotation) }\end{array}$} \\
\hline & & & $\begin{array}{l}\text { Factor } \\
\text { Loadings1 } \\
\text { (SCM) }\end{array}$ & $\begin{array}{l}\text { Factor } \\
\text { Loadings2 } \\
\text { (SCFLEX) }\end{array}$ & \begin{tabular}{|l} 
Factor \\
Loadings3 \\
(BUSPERF)
\end{tabular} \\
\hline Strategic supplier partnership (MB1SSP) & 5.18 & .976 & 0.76 & 0.28 & 0.21 \\
\hline Lean production (MNB5LP) & 5.21 & 1.09 & 0.78 & 0.25 & 0.24 \\
\hline Postponement Concept (MNB6PC) & 5.31 & 0.98 & 0.77 & 0.11 & 0.29 \\
\hline New Technology and Innovation (MB7TECH) & 4.94 & 1.26 & 0.71 & 0.33 & 0.33 \\
\hline \multicolumn{6}{|l|}{ Supply Chain Flexibility (SCFLEX): } \\
\hline Product flexibility (PRODFLEX) & 5.13 & 1.16 & 0.28 & 0.85 & 0.25 \\
\hline Volume flexibility (VOLFLEX) & 5.21 & 1.15 & 0.29 & 0.85 & 0.29 \\
\hline New product flexibility (NEWPFLEX) & 4.94 & 1.26 & 0.35 & 0.81 & 0.22 \\
\hline \multicolumn{6}{|l|}{ Business performance (BUSPERF): } \\
\hline Return on Sales (ROS) & 4.96 & 1.21 & 0.26 & 0.25 & 0.86 \\
\hline Return on Assets (ROA) & 4.94 & 1.16 & 0.26 & 0.25 & 0.87 \\
\hline Financial Performance (FINPERF) & 5.22 & 1.16 & 0.21 & 0.21 & 0.82 \\
\hline
\end{tabular}

Since data for the study were generated using multi-scaled responses, it was deemed necessary to test for reliability (Frohlich \& Westbrook; 2001, Agus, 2010). The internal consistency of each factor was examined using Cronbach Alpha. The reliability analysis was conducted by calculating the Cronbach's alphas for the main constructs in the study. Items that did not significantly contribute to the reliability were eliminated for parsimony purpose. The result indicated that the Cronbach's alpha measures for the three main constructs exceeded the threshold point of 0.70 suggested by Nunnally (1978). Alpha coefficients for SCM, supply chain flexibility and business performance ranged between 0.85 and 0.91 after the alpha maximization process were carried out, indicating internal consistency (Table 2). As a result, 10 items of the three constructs were retained for the confirmatory phase. The confirmatory factor analysis (CFA) or a measurement model using AMOS 5 was employed for examining construct validity of each scale by assessing how well the individual item measured the scale (Ahire, Golhar \& Waller, 1996; Agus, 2010). Specifically, the confirmatory factor analysis was used to detect the unidimensionality of each construct. The goodness of fit index (GFI) and comparative fit index (CFI) of the three constructs computed from the confirmatory factor analysis (CFA) exceeded the 0.90 criterion suggested by Hair et al. (1998), hence, establishing the construct validity. CFA showed all the items were loaded highly on their corresponding constructs, which supported the independence of the constructs and provided strong empirical evidence of their validity.

Table 2: Statistical Results

\begin{tabular}{|l|c|l|l|l|c|c|}
\hline \multirow{2}{*}{ CONSTRUCT } & \multicolumn{2}{|c|}{$\begin{array}{l}\text { Exploratory Factor Analysis-EFA } \\
\text { (Varimax Rotation) }\end{array}$} & \multicolumn{2}{|c|}{$\begin{array}{c}\text { Confirmatory Factor } \\
\text { Analysis (CFA) }\end{array}$} & \multicolumn{2}{c|}{ Reliability } \\
\cline { 2 - 7 } & Eigenvalue & $\begin{array}{l}\text { \% of } \\
\text { Variance } \\
\text { Explained }\end{array}$ & $\begin{array}{l}\text { Cummulative } \\
\text { Variance } \\
\text { Explained }\end{array}$ & GFI & CFI & $\begin{array}{l}\text { Cronbach } \\
\text { Alpha }\end{array}$ \\
\hline $\begin{array}{l}\text { Supply chain } \\
\text { management }\end{array}$ & 2.75 & 27.53 & 27.53 & 0.99 & 0.99 & 0.85 \\
\hline $\begin{array}{l}\text { Supply Chain } \\
\text { Flexibility }\end{array}$ & 2.61 & 26.13 & 53.66 & 0.99 & 0.99 & 0.91 \\
\hline $\begin{array}{l}\text { Business } \\
\text { performance }\end{array}$ & 2.55 & 25.46 & 79.12 & 0.99 & 0.99 & 0.90 \\
\hline
\end{tabular}

Extraction Method: Principal Component Analysis. Rotation Method: Varimax with Kaiser Normalization (KMO=0. 899, Bartlett's Test of Sphericity (chi-sq $=1778.259$, sig $=0.000)$ 


\section{FINDINGS}

\section{Pearson's Correlations between SCM, Supply Chain Flexibility and Business Performance}

The study also examined Pearson's correlations between SCM and supply chain flexibility (Table 3). The result suggested that the first supply chain flexibility dimension namely product flexibility had high correlations with SCM dimensions especially with 'New technology and innovation' $(r=0.57)$ and with 'Lean production' $(\mathrm{r}=0.49)$. Volume flexibility had high correlations with 'New technology and innovation' $(\mathrm{r}=0.57)$ and postponement concept $(\mathrm{r}=0.52)$. New product flexibility had strong correlations with all SCM programs especially with 'new technology and innovation' in SCM ( $\mathrm{r}=$ 0.56). The findings suggested that to enhance supply chain flexibility, a manufacturing company should invest its resources in incorporating lean production and technology and innovation in SCM to ensure that production runs effectively and efficiently with high supply chain flexibility.

Business performance indicators also exhibited positive correlations with SCM practices (Table 4). Specifically, 'Return on Sales' had high correlations with new technology and innovation $(r=0.54)$, lean production $(r=0.48)$ and strategic supplier partnership $(r=0.46)$. Meanwhile 'return on assets' had high correlations with new technology and innovation $(\mathrm{r}=0.54)$, lean production $(\mathrm{r}=0.48)$ and strategic supplier partnership $(\mathrm{r}=0.48)$. Financial performance also demonstrated strong correlations with new technology and innovation $(\mathrm{r}=0.45)$, strategic supplier partnership $(\mathrm{r}=0.43)$ and lean production $(r=0.41)$. Hence, the result suggested that investment in new technology and innovation in SCM and adoption of lean production would be able to improve 'return on sales', 'return on assets' and most importantly financial performance (Agus, 2010).

Table 3: Pearson's Correlation between SCM and Supply Chain Flexibility

\begin{tabular}{|l|l|c|c|c|}
\hline \multirow{2}{*}{ Supply chain management (SCM) } & \multicolumn{3}{|c|}{ Supply Chain Flexibility } \\
\cline { 3 - 5 } & $\begin{array}{c}\text { Product flexibility } \\
\text { (PRODFLEX) }\end{array}$ & $\begin{array}{c}\text { Volume flexibil- } \\
\text { ity (VOLFLEX) }\end{array}$ & $\begin{array}{c}\text { New product } \\
\text { flexibility } \\
\text { (NEWPFLEX) }\end{array}$ \\
\hline 1 & Strategic supplier partnership (MB1SSP) & $0.47(* *)$ & $0.47(* *)$ & $0.54(* *)$ \\
\hline 2 & Lean production (MNB5LP) & $0.49(* *)$ & $0.41(* *)$ & $0.54(* *)$ \\
\hline 3 & Postponement Concept (MNB6PC) & $0.49(* *)$ & $0.52(* *)$ & $0.51(* *)$ \\
\hline 4 & New Technology and Innovation (MB7TECH) & $0.57(* *)$ & $0.57(* *)$ & $0.56(* *)$ \\
\hline
\end{tabular}

1. $\dagger$ if $\mathrm{p}<0.10, *$ if $\mathrm{p}<0.05 ; * *$ if $\mathrm{p}<0.01 ; * *$ if $\mathrm{p}<0.0012$. All t-tests are two-tailed

Table 4: Pearson's Correlation between Supply Chain Management and Business Performance

\begin{tabular}{|l|l|c|c|c|}
\hline \multicolumn{2}{|l|}{ Supply chain management (SCM) } & \multicolumn{3}{|c|}{ Business Performance } \\
\cline { 3 - 5 } & $\begin{array}{c}\text { Return on Sales } \\
\text { (ROS) }\end{array}$ & $\begin{array}{c}\text { Return on Assets } \\
\text { (ROA) }\end{array}$ & $\begin{array}{c}\text { Fin. Performance } \\
\text { (FINPERF) }\end{array}$ \\
\hline 1 & Strategic supplier partnership (MB1SSP) & $.46\left(^{* *}\right)$ & $.48(* *)$ & $.43(* *)$ \\
\hline 2 & Lean production (MNB5LP) & $.48(* *)$ & $.48(* *)$ & $.41(* *)$ \\
\hline 3 & Postponement Concept (MNB6PC) & $.40\left(^{* *}\right)$ & $.37(* *)$ & $.36\left(^{* *}\right)$ \\
\hline 4 & New Technology and Innovation (MB7TECH) & $.54(* *)$ & $.54(* *)$ & $.45(* *)$ \\
\hline
\end{tabular}

1. $\dagger$ if $\mathrm{p}<0.10, *$ if $\mathrm{p}<0.05 ; * *$ if $\mathrm{p}<0.01 ; * * *$ if $\mathrm{p}<0.001 \quad 2$. All $\mathrm{t}$-tests are two-tailed 


\section{Structural Equation Modeling}

A SEM model was employed to investigate simultaneous linkages that allow a researcher to determine the relative strength of relationships between variables. The linkages between supply chain management (SCM), supply chain flexibility (SCFLEX), and business performance (BUSPERF) were depicted in the model shown in Figure 2. To support the assumption regarding the fitness of the SEM model with the empirical data, the acceptance of the null hypothesis of the overall model was expected. Hence, in this test of goodness of fit for the structural equation modeling, the resulting probability value should be higher than 0.05 to support the overall null hypothesis of the SEM model.

Findings of the SEM indicated that the resulting Chi-square value was 34.46 with 32 degrees of freedom and probability value of 0.35 (Figure 2). The result supported the null hypothesis that the SEM model had a good fit ( $\mathrm{H}_{0}$ ). The probability value was considerably substantial (p-value $>0.05$ ), in supporting the proposition that the overall model fitted the data. Furthermore, other statistical structural indices such as Goodness of fit index $(\mathrm{GFI}=0.97)$, Bentler comparative fit index $(\mathrm{CFI}=0.99)$, Bollen Incremental Fit Index $(I F I=0.99)$ and Tucker and Lewis Index $(T L I=0.99)$ further suggested that the model had a satisfactory fit. Since the probability value and structural modeling indices were well above the recommended level, the model was considered to be a reasonable representation of the data (Hair et al., 1998; Agus, 2001).

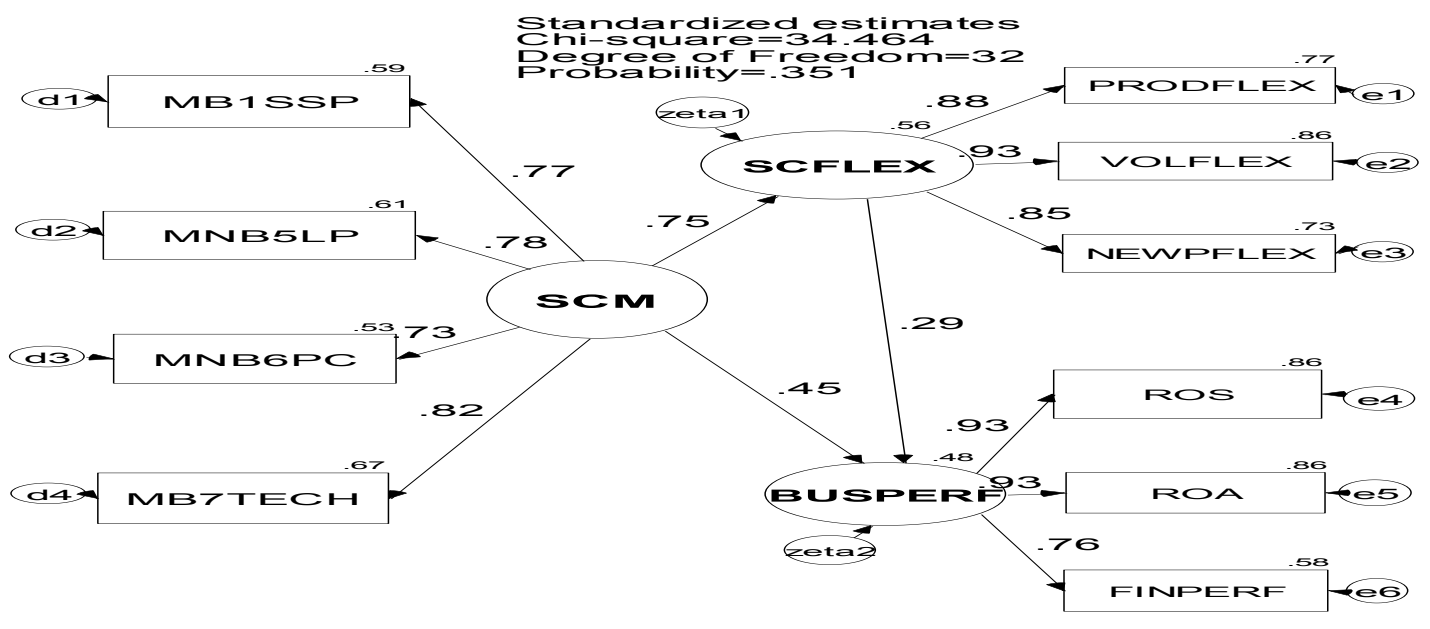
Figure 2: The Structural Linkage between SCM, Supply Chain Flexibility and Business
Performance

The direct structural effect of SCM on supply chain flexibility (SCFLEX) was high with structural effect value of 0.75 . The standardized structural coefficient of SCM on supply chain flexibility was associated with low standard error (0.11) and non-zero critical ratio (10.48), which indicated that the structural effect between these two constructs, was positive and the relationship was significant. The direct structural effect of SCM on business performance was also quite high given complex linkages and significant (structural effect value of 0.45 ) with low standard error $(0.15)$ and non-zero critical ratio (4.64). In addition, supply chain flexibility exhibited only substantial but positive structural effect on business performance (structural direct effect $=0.28$ ), with low standard error $(0.10)$ and significant critical ratio (3.14). Therefore, there were enough evidences to accept all three propositions (

$H_{1}, H_{2}$ and $H_{3}$ were supported). Firstly, SCM has a positive effect on supply chain flexibility $\left(H_{I}\right)$. Secondly, supply chain management has a positive structural effect on business performance $\left(H_{2}\right)$. Thirdly, supply chain flexibility has a positive structural effect on business performance $\left(H_{3}\right)$. In addition, the result also indicated that there was a mediating effect of supply chain flexibility in the linkage between SCM and business performance $\left(H_{4}\right)$. The indirect effect was 0.21 and the total effect was 0.66 (Table 5). Since the structural direct effect of SCM on business performance was also significant (structural effect $=0.45$ ), therefore we can conclude that supply chain flexibility had a partial mediating effect in the linkage between SCM and business performance (Baron \& Kenny, 1986). Overall, it is essential to reaffirm that SCM can ultimately improve business performance of manufacturing companies in Malaysia 
Investigating the structural loadings of each SCM determinants (Figure 2) on the main construct, apparently 'new technology and innovation' (structural loading $=0.82$ ) had the highest contribution towards supply chain management implementation. This was followed by 'lean production' (structural loading $=0.78$ ), 'strategic supplier partnership' (structural loading $=0.77$ ), and lastly 'postponement concept' (structural loading $=0.73$ ). All of these variables had significant probability values (critical values $\geq 2.00$ ), giving statistical evidence that the contributions of these variables toward the overall supply chain management construct were significant and positive. Most importantly, SCM also had high influences on performance dimensions especially volume flexibility (structural loadings $=0.93)$, ROS (structural loadings $=0.93)$ and ROA (structural loadings $=0.93$ ).

Table 5: Structural and Measurement Results of the SEM Model

\begin{tabular}{|c|c|c|c|c|}
\hline (i)Constructs and indicators & $\begin{array}{l}\text { Std. } \\
\text { Loadings }\end{array}$ & Std. errors & Critical Ratio & $\begin{array}{l}\text { Probability } \\
\text { (significant) }\end{array}$ \\
\hline \multicolumn{5}{|l|}{ Supply chain management (SCM): } \\
\hline Strategic supplier partnership (MB1SSP) & 0.77 & 0.09 & 11.46 & 0.00 \\
\hline Lean production (MNB5LP) & 0.78 & 0.10 & 11.67 & 0.00 \\
\hline Postponement Concept (MNB6PC) & 0.73 & 0.07 & 11.75 & 0.00 \\
\hline New Technology and Innovation (MB7TECH) & 0.82 & 0.12 & 12.22 & 0.00 \\
\hline \multicolumn{5}{|l|}{ Supply Chain Flexibility:(SCFLEX) } \\
\hline Product flexibility (PRODFLEX) & 0.88 & 0.05 & 20.91 & 0.00 \\
\hline Volume flexibility (VOLFLEX) & 0.93 & 0.05 & 19.97 & 0.00 \\
\hline Launch/New product flexibility (NEWPFLEX) & 0.85 & 0.05 & 19.64 & 0.00 \\
\hline \multicolumn{5}{|l|}{ Business performance $(\mathrm{PQP})$ : } \\
\hline Return on Sales (ROS) & 0.93 & 0.09 & 22.53 & 0.00 \\
\hline Return on Assets (ROA) & 0.93 & 0.04 & 22.66 & 0.00 \\
\hline Financial Performance (FINPERF) & 0.76 & 0.05 & 15.66 & 0.00 \\
\hline \multicolumn{5}{|l|}{ (ii) Exogenous/endogenous Path } \\
\hline a. $\mathrm{SCM} \rightarrow \operatorname{SCFLEX}\left[{ }^{H_{1}}\right.$ is supported] & 0.75 & 0.11 & 10.48 & 0.00 \\
\hline b. $\mathrm{SCM} \rightarrow \mathrm{BUSPERF}$ [ ${ }^{\mathrm{H}_{2}}$ is supported] & 0.45 & 0.15 & 4.64 & 0.00 \\
\hline c. SCFLEX $\rightarrow$ BUSPERF [ ${ }^{H_{3}}$ is supported] & 0.28 & 0.10 & 3.14 & 0.002 \\
\hline d. $\mathrm{SCM} \rightarrow$ SCFLEX $\rightarrow$ BUSPERF & \multicolumn{3}{|c|}{$\begin{array}{l}\text { Indirect effect }\left(.75^{*} .28\right)=0.21 \\
\text { Total Effect }(.45+.21)=0.66\end{array}$} & 0.00 \\
\hline
\end{tabular}

\section{CONCLUSION AND IMPLICATIONS}

To meet the increasing demand of high-quality and technological goods from sophisticated local and overseas markets, manufacturing companies must continuously improve their efforts in technology and quality operations of SCM. Supply chain management provides a vision that focuses everyone in an organization on product, production and quality improvements. The associations and effects of the four SCM practices were evaluated using Pearson's correlations and structural equation modeling (SEM). The results of the study assist in the understandings of how SCM determinants influence supply chain flexibility and business performance. The result indicates that manufacturing companies should emphasize greater attention to the technology and innovation and lean production aspects of the SCM processes and a greater degree of management support for SCM implementations. 
The conclusion emerging from this study is that SCM would ultimately result in positive gains. The results validate some of the key linkages and support beliefs and evidences by researchers regarding the relationships between SCM, supply chain flexibility and business performance. It is also important to note that this study attempts to enrich the literature review and make a contribution in supply chain management-related studies. This study to some extent helps in resolving controversy about the magnitude and measurements of performance gains from adopting SCM. By strengthening supply chain management, improved performance will likely to occur. In short, the findings of this study suggest that SCM would be able to support and accommodate the supply chain flexibility as well as increase the level of business performance. SCM would no doubt increase the supply chain flexibility by improving product flexibility, volume flexibility and launch flexibility. This subsequently would lead to better business performance. 


\section{REFERENCES}

Agus, Arawati. 2001. A linear structural modelling of total quality management practices in manufacturing companies in Malaysia. Total Quality Management, 12(5), 561-573.

Agus, Arawati \& Hassan, Za'faran, 2008. The Strategic Supplier Partnership in a Supply Chain Management with Quality and Business Performance. International Journal of Business and Management Science. Vol. 1(1), 124-143.

Agus, Arawati, 2008, The Importance of Incorporating New Technology and Innovation In Supply Chain Management Processes in Enhancing Performance, Proceedings: 16 th PBEAM 2008:Innovation For Sustainable Future:Visions For 2020, QUT, Brisbane, Australia.

Agus, Arawati \& Hassan, Za'faran, 2009, The Power of New Technology and Innovation in SCM Towards Enhancing Postponement Flexibility and Customer Related Performance, Proceedings of 6th SMES Global Economy Conference 2009:Global Financial Crisis: Challenges Opportunities And Strategies For Recovery, Beijing, China 5-6 Dec 2009

Agus, Arawati. 2010a, The importance of new technology and innovation in SCM in enhancing production performance and product quality performance: an investigation on mediating effect. Global Review of Business and economic Research, 6(2), 19-38.

Agus, Arawati. 2010b, Supply Chain Management, Process Performance and Business Performance, Conference of the International Journal of Arts and Sciences, Rome, Itali, 22-25.

Ahire, S.L.,Golhar, D. Y. \& Waller, M. A. 1996. Development and validation of QM implementation constructs, Decision Sciences., 27(1): 23-55.

Alvarez-Gil, M.J. 1994, Capital budgeting and flexible manufacturing, International Journal of Production Economics, No.36, pp.109-28.

Baron, R. M., \& Kenny, D. A. (1986). The moderator-mediator variable distinction in social psychological research: Conceptual, strategic and statistical considerations. Journal of Personality and Social Psychology, 51,1173-1182.

Bhasin, S. 2008. Lean and Performance Measurement, Journal of Manufacturing technology Management. Vol. 19, No.5, pp:670-684.

Bickman, L. 2000. Summing up program theory. New Directions for Evaluation, 87, 103-111.

Bollen, Kenneth A. 1989. Structural Equations with Latent Variables. New York: John Wiley and Sons.

Brill, D., Mandelbaum, M. 1989, On measures of flexibility in manufacturing systems, International Journal of Production Research, Vol. 27 No.5, pp.747-56.

Christopher, M.1998. Logistics and supply chain management: Strategies for reducing cost and improving service, Financial Times. Pitman Publishing.

Cleveland, G., Schroeder, R., \&Anderson, J. 1989, A theory of production competence, Decision Sciences, Vol. 20 No.4, pp.655-68.

Frohlich, M. T., \& Westbrook , R., 2001. Arcs Of Integration: An International Study Of Supply Chain Strategies, Journal of Operations management, 19, 185-200.

Ganeshan, Ram \& Harrison, Terry, P. 1999. An Introduction to Supply Chain Management online internet, http // silmaril.smeal.psu.edu / misc / supply_chain_intro.html. pp. 1-2.

Gerwin, D. 1993, Manufacturing flexibility: a strategic perspective, Management Science, Vol. 39 No.4, pp.395-410.

Hair, J.F., Anderson, R.E., Tatham, R.L. \& Black, W.C. 1998. Multivariate data analysis,_Englewood Cliffs, NJ: Prentice-Hall.

Investorwords, 2010. [http://www.investorwords.com/5775/ROS.html. Accessed 06 September 2010] Jaikumar, R. 1986, Postindustrial manufacturing, Harvard Business Review, Vol. 64 No.6, pp.69-76.

Lieberman, M. \& Montgomery, D. 1988, "First mover advantages", Strategic Management Journal, Vol. 9 No.1, pp.41-58. 
Joreskog, K. \& Sorbom D. 1989. LISREL 7: A guide to the Program and Applications. 2d ed. Chicago: Statistical Package for the Social Sciences.

Li, S., Ragu-Nathan, B., Ragu-Nathan, T.S., \& Rao, S.S. 2006. The impact of supply chain management practices on competitive advantage and organizational performance. Omega, 34, 107-124.

Lummus, R.R. and Vokurka, R.J. 1999, Defining supply chain management: a historical perspective and practical guidelines, Industrial Management \& Data Systems, Vol. 99 No. 1, pp. 11-17

Mueller, Ralph O. 1996. Basic principles structural equation modelling: An introduction to LISREL and EQS. New York: Springer.

Nunnally, J. 1978, Psychometric Theory, McGraw-Hill, New York, NY.

Quinn, F.J. 1997, What's the buzz? Logistics Management, Vol. 36 No. 2, pp. 43-7.

Riley, M. \& Lockwood, A. 1997, Strategies and measurement for workforce flexibility: an application of functional flexibility in a service setting, International Journal of Operations \& Production Management, Vol. 17 No.4, pp.413-9.

Robinson, W., Fornell, C., \& Sullivan, M. 1992, Are market pioneers intrinsically stronger than later entrants? Strategic Management Journal, Vol. 13 No.6, pp.609-24.

Singh, G. K. G., \& Singh, S.K. G. 2008. Malaysian graduates's employability skills, UNITAR EJournal, Vol 4 (1):15-45.

Suchman, E.A. 1967. Evaluative Research: Principles and Practice in Services and Social Action Programs. New York: Russell Sage Foundation, 1967

Schonsleben, P. 2004. Integrated Logistics Management: Planning and Control if Comprehensive Supply Chains, Boca Raton, FL.: St, Lucie Press.

Van Hoek, R.I. 2001. The rediscovery of postponement: a literature review and directions for research, Journal of Operations Management, Vol. 19 pp.161-84.

Windischer, A. \& Grote, G. 2003. Success factors for collaborative planning, in Seuring, S., Miller, M., Goldbach, M., and Schneidewind, U. (Eds), Strategy and Organizations in Supply Cain, Physica, Heidelberg: 131-46

Womack, James P. \& Daniel T. Jones. 2003. Lean Thinking. Free Press. p. 352.

Upton, D. 1994, The management of manufacturing flexibility, California Management Review, Vol. 36 No.1, pp.72-89.

Vickery, S., Dröge, C., \& Markland, R. 1997, Dimensions of manufacturing strength in the furniture industry, Journal of Operations Management, Vol. 15 pp.317-30.

Weiss, C.H. 1998. Evaluation (2nd Ed.). Englewood Cliffs, NJ: Prentice Hall, 1998. 